\title{
GROWTH AND DEVELOPMENT OF THE COMPANY AS A FACTOR IN IMPROVING BUSINESS EFFICIENCY
}

\author{
Vuk Bevanda ${ }^{1}$ \\ Aleksandra Živaljević ${ }^{2}$ ii \\ Biljana Pejović 3
}

DOI: https://doi.org/10.31410/LIMEN.2020.191

\begin{abstract}
In modern business conditions, companies must be ready to respond at any time to the challenges, requirements and limitations that come from the environment. The development of a company is often described as a set of changes, i.e. metamorphoses, which it experiences during the adaptation to the challenges and threats that come from the environment, which are constantly present in the business process of the company. Broadly speaking, the development of a company represents the totality of the changes that it experiences in its life cycle, during its existence and business. The growth of a company is a change in its size, which is reflected in the number of employees, profit size, size and strength of installed capacities, market opportunities, market share. The paper aims to analyze the role and importance of growth and development in the business of modern companies, as well as their impact on improving business efficiency.
\end{abstract}

Keywords: Growth, Development, Company, Business, Market, Factors.

\section{COMPANY'S GROWTH GOALS}

I

f we look at the goal as a future situation or state to which the company aspires, then we can define growth goals as the company's effort to provide such a size, organizational structure and system of business relations with the environment, which will allow it to use available resources more efficiently, and that it more effectively achieves its economic role and goals.

The growth of a company is not a goal itself, but a path that leads the company to achieve higher profit, better market position and increase the material basis of development.

With the help of growth, the company is able to more efficiently implement existing goals and take on new tasks and jobs in performing its activities, work and business processes.

"A growing business is expanding in one or more ways. There is no single metric used to measure growth. Instead, several data points can be highlighted to show a company is growing. These include revenue, sales, company value, profits, number of employees, number of customers." (https://www.act.com/en-uk/business-growth, accessed on 12.11.2020.)

Faculty of Social Sciences, Bulevar umetnosti 2a, Belgrade, Serbia

Higher Colleges of Technology, Department of Business, United Arab Emirates

Faculty of Social Sciences, Bulevar umetnosti 2a, Belgrade, Serbia 
Practice shows that the growth of a particular company should be focused on (Živković et al., 2014):

- increase of market share,

- elimination of bottlenecks in performing activities,

- more efficient integration into the international division of labor,

- reducing operating costs and increasing profits on that basis,

- reducing the effects of competition.

Growth goals are the primary management decisions in a company's development plans. Goals are the basis for defining growth strategies, and then individual plans. The goals of the company are set based on research and forecasting the future in the area in which the company exists and operates.

Achieving the goals of enterprise growth leads to the achievement of broader goals of social and economic development, ensures more effective use of existing capacities and resources, as well as an increase in overall social well-being (Posza, 2020).

Growth goals need to be realistically set and dimensioned on the basis of scientific and exact methods, taking into account previous experiences of company's practice. Carefully and precisely set goals for the growth of the company become its long-term obligation, but also a criterion for assessing the rationality of planning decisions and directions of business activities, as well as the standard of business control.

"Growth is interpreted as a sign of health, vitality and strength. In such dynamic and competitive environments, companies have to grow and develop continuously. The growth target is closely related to the utility function of the company's managers. The concept of development of the company goes a little further by proposing both quantitative and qualitative changes. It is broader than growth because it includes qualitative variations of the company." (https://entrepbusiness.com/the-growth-and-development-of-a-company/, accessed on 05.11.2020.)

\section{COMPANY'S DEVELOPMENT POLICY}

In the broadest sense, politics implies the skill of governing a state or an organization. A policy is a set of attitudes, principles or criteria that guide decision-making and action in repetitive conditions.

Within the company as a business entity, the policy is formulated for its organizational parts (business units) or for certain areas of activity of special importance for the company.

Development policy is defined as a set of principles and criteria that a company applies in the process of managing its long-term business. It is based on long-term forecasting of market, technological and social components and trends. An important condition for a successful development policy of the company is that it is based on the longest possible period and on the widest possible spatial horizon.

Through development policy, the company forms the basis of its future work and business. Therefore, it provides the company with visions of development and the basic philosophy on the basis of which that vision will be realized. 
With the set and defined development policy, the company determines future guidelines on (Živković et al., 2014):

- development financing methods,

- markets in which it will compete,

- technology and production program,

- attitude towards expected changes and requirements of the environment,

- development of its parts and subsystems, as well as their mutual relations,

- directions and dispersion of its future activity, business activities, etc.

Development policy begins with long-term forecasting, in order to experience its realization and application in the practice of business operations through a growth strategy and specific development projects.

Managing the growth and development of a company involves resolving a number of complex issues and making business decisions that are, by their nature, of a strategic character.

The growth strategy involves making decisions about the directions, methods, pace and flexibility of growth.

We can define strategy as a way to achieve future goals of the company. Once the company has set goals and business policies to guide it in achieving its goals, it approaches the definition of a strategy.

The strategy selection process itself takes place in several stages. First, an analysis of the influential environmental factors that affect the company's business is performed. Opportunities and threats from the environment are opposed to the resources and opportunities, i.e. the advantages and weaknesses of the company itself.

The choice of a specific strategy is made on the basis of a number of criteria and parameters. One of them relates to market coverage and the market position that the future strategy should provide (Pirić et al., 2020). The second criterion refers to the competitive position that the company can achieve by choosing a particular strategy. Through that market position, it occupies an appropriate place or market share.

The third criterion refers to the amount of return on invested funds (invested capital) that the given strategy brings to the company in the future.

An important criterion are the sources and resources (material and human resources) that are necessary for the realization of a certain strategy. The availability and use of these resources are factors in the realization of the development and business strategy of the company.

The chosen strategy must be in line with and correlated with the goals and policies of the company. Choosing an adequate development strategy means making decisions about the directions, methods and growth rate of the company. The chosen strategy implies the harmonization of these components and their actions in the period in which the strategy will be implemented.

\section{COMPANY'S GROWTH DIRECTIONS}

There are many different views and approaches to growth directions and growth strategies: "Growth strategies usually start by identifying and accessing opportunities within your market. 
They go beyond your business and marketing plans, which detail how you're going to meet specific business targets. Growth strategies are important because they keep your company working towards goals that go beyond what's happening in the market today. They keep both leaders and employees focused and aligned, and they compel you to think long-term." (https://www.prophet.com/2017/09/develop-successful-business-growth-strategy/, accessed on: 15.11.2020.)

"Businesses aim to use their sources efficiently in order to gain advantages in competition and survive for many years. However, with this aim come several problems. Competitors, consumers, financial institutions, suppliers, trade-unions, technological developments, economical and judicial factors constitute impediments in the way of attaining objectives. Business management determines growth strategies following structures of businesses and the competitive environment by applying analysis and methods which will eliminate those impediments." (Durmaz, Y., İlhan, A., 2015)

Starting from the characteristics of the markets and products as the basic components of the source of growth, there are four possible growth directions of the company (Živković et al., 2014):

1) increase in sales of the existing product on the existing market - penetration,

2) increase in sales of the existing products on new markets - market development,

3 ) introduction of new products on existing markets - product development,

4) introduction of new products on new markets - diversification.

Table 1. Combining products and markets

\begin{tabular}{|c|c|c|}
\hline \multirow{2}{*}{$\begin{array}{c}\text { Mission } \\
\text { (Market) }\end{array}$} & Current & New \\
\cline { 2 - 3 } & Market penetration & Product development \\
\hline Current & Market development & Diversification \\
\hline New & Source \\
\hline
\end{tabular}

Source: Živković et al., 2014

Based on the above, we can identify two possible directions of company's growth:

(1) Expansion - which is based on the existing activity of the company and the following strategies:

- market penetration,

- market development,

- product development.

(2) The second direction of growth is diversification, which can be:

- horizontal,

- vertical,

- conglomerate.

Expansion and diversification as two directions of growth are not mutually exclusive, and their participation in the development of the company and its activities depends on the impact of a number of factors, as well as development opportunities and available resources of the company. 


\subsection{Expansion as a direction of company's growth}

Expansion, as a direction of the company's growth, is based on the development of the existing market and the improvement of the existing assortments and products of the company.

Expansion implies constant competition with other, existing and new producers in the branch. A company that has chosen expansion as its direction of growth must continuously monitor and analyze the behavior and operation of the competition, market shares of individual companies in the economic branch, areas of operation and possible collisions with the competition. It is necessary to consider and anticipate the possibilities of increasing the primary demand for the product and whether it is possible to do so without significantly endangering competition.

A successful company strives to provide space for its growth through functional and adaptive innovations in its product assortment, which allows the existing product to remain in the production program as long as possible as an active resource for company's growth.

The expansion is based on the following strategies (Živković et al., 2014):

1) Market penetration strategy - which implies the development of the company on the basis of the existing product within the existing market. Penetration is based on increasing the sales volume of companies in the existing market and the existing market structure. If the market is more saturated with the existing product, the company must choose to stimulate selective demand, i.e. to attract consumers of products of the same purpose, which were previously purchased from the competition. If the market is not oversaturated with existing products, the company can increase sales by increasing the number of customers or by increasing the level of consumption or earnings per consumer.

2) Market development strategy - which is based on the introduction of an existing product into new markets. New markets can be: regional, national or international. The need to expand the market through territorial dispersion and increase exports affirms the orientation of companies to the international market. In this way, the company with its product assortment is more strongly involved in the international division of labor.

3) Product development strategy - within which the company seeks to increase profits in the existing market, relying on innovations in the existing production program and area of activity (production). Innovations include: changing the style, dimensions, design, quality or other components of the existing product and assortment.

4) Strategy of expanding production lines and assortment - is based on conquering, introducing and adding new products and models within the existing assortment and production program of the company.

\subsection{Diversification}

Diversification, as a direction of growth, implies an increase in the number of products in the existing product assortment of the company. They contain technological and market disparities among products, and as a consequence, the size of the company increases.

Diversification is a direction of growth that is characteristic for companies with a dynamic environment. Companies opt for diversification in order to ensure their market survival, stability of sales and revenues, more efficient use of material and human resources and adaptation to new, changed customer needs. 
Before choosing diversification as the direction of growth, the company must perform a detailed analysis of a large number of influencing factors, which individually have opposite effects. Also, the company must be ready to face the actions of the competition on the market.

As it was mentioned earlier, diversification can be (Živković et al., 2014):

- horizontal,

- vertical,

- conglomerate.

Horizontal diversification implies that the production program of the company includes products that differ from each other in technological basis and market purpose, but belong to the same branch of activity. In this way, the company completes its offer and more efficiently uses its production capabilities for the acquired market positions.

Vertical diversification is the growth of a company that includes several successive, technological and business-separate phases of production and marketing of a particular product. The company itself begins to produce some materials, raw materials, energy, semifinished products that it previously bought from suppliers, and later incorporates them into its final product.

Vertical diversification may include the introduction of new, additional processing stages, as well as new sales channels.

Conglomerate diversification means that a company produces products that belong to different types and branches of activity. Technological, market and production diversification are present in practice.

An economic incentive for a company to opt for conglomerate diversification can be antitrust legislation related to the maximum volume of supply in one branch. Conglomerate diversification provides unlimited opportunities for company's growth in market conditions.

\section{METHODS OF BUSINESS GROWTH}

The method of growth is the way in which a company realizes its defined development needs and goals.

The choice of individual growth methods is influenced by a large number of internal and external factors. Among them, a significant factor is the amount of financial resources that the company can provide or invest. Its significance is reflected in the fact that the growth of the company is always conditioned by an appropriate material, i.e. financial investments.

Possible methods of company's growth are (Živković et al., 2014):

- internal growth method,

- external growth method,

- combined growth method,

- joint venture.

The method of internal growth implies that the company decides to build its own new capacities and to develop new products. This method implies building new capacities and new financial investments. 
The need for internal growth most often arises in response to increasing demand for existing company's products.

For the realization of this method of growth, it is necessary for the company to have significant own financial resources, to have the appropriate personnel research and development potential, and to be ready and able to take the risk on the market.

The method of external growth comes down to integration, i.e. merging with other companies that already have the appropriate capacity and produce certain types and assortments of products.

In order to achieve integration, there must be a willingness and mutual economic interest of the company to merge with the integrating company. Integration is always motivated by economic goals and the perspective of increasing profits. It implies the mutual benefit that is achieved by merging companies.

Integration as a method of company's growth provides a number of positive effects:

- use of the existing sales network, as well as existing sources of supply,

- achieving a higher total mass of profit,

- savings in common costs,

- using the effects of the existing positive market position and reputation of the product,

- the possibility of using patents, etc.

The combined method of growth is achieved by a combination of internal and external methods of growth. This method combines the internal capabilities of the company and interested business partners, subcontractors and others.

The combined method is the most efficient way to optimize the size and structure of the company, as well as the business of a particular economic branch.

Joint Venture is a cooperation between companies from different countries, which is based on joint investment in a particular project, i.e. the establishment of a joint company, joint production and market appearance. This method optimizes the advantages of domestic and foreign companies in certain markets.

Joint ventures are now used mainly by large international corporations. In that way, they penetrate the markets they are interested in, provide themselves with the access to rare natural resources, avoiding the provisions of the antitrust laws of the country in which their headquarters are located. They use the cheap labor of the host country as well as its market. Through joint investment, the host country gets the necessary funds for its development, increases its presence and participation in the foreign market, provides "know-how" and the like.

External growth can also be provided by creating mergers, acquiring other companies or joining several companies in joint research and development projects.

\section{GROWTH STIMULATING FACTORS}

"A business is defined by various factors, however, the prime element that recognizes and brands a business is its growth. Every company desires growth to secure a strong market 
presence irrespective of whether the company is a startup or a well-established organization. Growth is a need to keep the legacy going. Numerous factors affect the growth and development of a company, that foster a position in the lead." (https://cioviews.com/factorsthat-affect-the-growth-of-a-business/, accessed on 16.11.2020.)

There are different classifications of influential factors that have a positive and stimulating effect on the growth and development of the company. They can come from the company itself or from its business environment (Živković et al., 2014):

1) According to the nature of action, incentive factors are divided into: market, technical technological, social and personnel-organizational.

2) According to certainty, factors are divided into: state factors and development factors. Factors of the situation are: achieved business volume, the position of the company on the market, structure of production and technology, existing location, available funds (capital). Development factors include: market development perspectives, communications, technology, research, raw materials base, state economic policy instruments and the like.

3) Internal and external factors

Internal growth factors of the company include: available financial resources, the need to harmonize capacities in order to optimize them, level of development of existing research, the need to complete the assortment, goals set in development plans, management initiative, staff availability, decision-making system, organizational culture and climate development, and more.

External factors refer to challenges, threats and opportunities that arise as a consequence of social, market and technological factors of business. These factors include: development of science and technology, market development, state policy measures (stimulating economic policy), development of economic relations with foreign business partners, traffic development, and others.

It is extremely important for a company to anticipate and measure external factors and to anticipate their impact on the company's future operations. This is significant because the company has almost no influence on many of these factors.

Incentive factors cause an increase in financial, personnel, research and development, market and other opportunities and indicators of the company.

The growth of the company is based on the harmonization of various interests and working conditions of its components - subsystems.

With the increase in the size of the company, there is a change in its economic strength concerning competing companies and environmental factors. This creates conditions for further and continuous growth and expansion of the company.

With the help of incentive factors from the environment, the company can grow as long as it finds ways and mechanisms for its operations in the market, and the creation of additional profit within the existing activity.

Theoretically, a company can grow as long as it finds strategies and ways that allow it space and engagement activities, while making additional profit. However, in practice, many limits slow down the growth of a company or make it economically unprofitable. The natural limit 
of growth consists of human, organizational and technical-technological characteristics of the process in certain areas of business.

\section{LIMITING FACTORS OF COMPANY'S GROWTH AND DEVELOPMENT}

In practice, many factors appear as a constraint on the further growth of the company, whether they slow it down, or are economically unprofitable and redundant.

Restrictive factors of company's growth and development are divided into external and internal (Živković et al., 2014).

a) External factors include:

- the existence of legal restrictions on further growth (antitrust regulations, etc.),

- difficult procurement of necessary material components and resources,

- impossibility or poor conditions of securing financial resources,

- insufficient development of traffic and trade network,

- inability to conquer new markets due to existing strong competition,

- reducing demand and narrowing market opportunities,

- disincentive measures of state economic policy (restriction of imports and exports, exchange rate changes, etc.).

b) Internal limiting factors include:

- inadequate human and work potential in terms of the number of employees, their expertise, motivation to work, etc.,

- the wrong strategy of the company's growth so far (it can also be an incentive factor),

- technical-technological solutions in performing the activities of the company. At a certain degree of capacity utilization, their further expansion can become too expensive and cost more than building new capacities.

The company and its management bodies should make a realistic assessment of the actions of both incentive and limiting factors - in order to make appropriate decisions about the future directions of growth development of the company. These assessments and decisions are the basis for undertaking managerial actions of companies in the field of growth and development.

\section{CONCLUSION}

Growth and development of a company should not be viewed separately, but as processes that take place simultaneously and synchronized. Growth and development of a company arise as a consequence of its constant aspiration to adapt to changes in the environment, to take advantage of new market opportunities, avoid dangers, and ensure the continuity of efficient business.

In order for a company to take advantage of the effect of size and economies of scale that are a consequence of the growth process, it must make changes in the internal organizational structure, as well as in the business structure of its activities.

Managing the growth and development of a company means making decisions about the goals, sources, directions, methods and pace of enlargement of its size, in accordance with internal and external factors and circumstances that affect the growth of the company.

The consequence of the growth and development of the company should be constant improvement of the management system and the establishment of more harmonious relations 
between the company and the environment. That way, further preconditions are created for improving business efficiency and successful business results.

\section{REFERENCES}

Durmaz, Y., İlhan, A. (2015), Growth Strategies in Businesses and A Theoretical Approach, International Journal of Business and Management; Vol. 10, No. 4; 2015, ISSN 18333850 E-ISSN 1833-8119, Published by Canadian Center of Science and Education, pp. 210-214

Factors that Affect the Growth of a Business, https://cioviews.com/factors-that-affect-thegrowth-of-a-business/, accessed on 16.11.2020.

Jovanović, P. (2013), Upravljanje investicijama, VŠPM, Beograd

Jovetić, S. (2015), Merenje performansi preduzeća, Ekonomski fakultet, Kragujevac

Pirić, V., Martinović, M. \& Koričan Lajtman, M. (2020) Socio-demographic Variables Forming a Perception of Corporate Image Brand in the Croatian Banking Industry, Balkans Journal of Emerging Trends in Social Sciences, Vol. 3, No. 2, 2020, ISSN 2620164X, Published by Association of Economists and Managers of the Balkans, pp. 96-111, DOI: 10.31410/Balkans.JETSS.2020.3.2.96-111

Posza, A. (2020), Real Option Analysis of Venture Capital Investments, Balkans Journal of Emerging Trends in Social Sciences, Vol. 3, No. 1, 2020, ISSN 2620-164X, Published by Association of Economists and Managers of the Balkans, pp. 64-77, DOI: 10.31410/Balkans.JETSS.2020.3.1.64-77

Sloman John, Garratt Dean (January 1, 2019), Essentials Of Economics, 8th New edition, ISBN-10: 1292239271, ISBN-13: 978-1292239279, United Kingdom: PEARSON

Sloman John, Garratt Dean, Guest Jon, Jones Elizabeth (May 9, 2016), Economics For Business, 7th edition, ISBN-10: 1292082100, ISBN-13: 978-1292082103, Philadelphia, Pennsylvania, USA: Trans-Atlantic Publications, Inc.

Successful Business Growth Strategies: 5 Key Components, https://www.prophet.com/2017/09/develop-successful-business-growth-strategy/, accessed on: 15.11.2020.

Ten Key Factors in developing company Growth Strategies, https://endeavor.co.za/2017/02/ten-key-factors-in-developing-company-growthstrategies/, accessed on 13.11.2020.

The growth and development of a company, https://entrepbusiness.com/the-growth-anddevelopment-of-a-company/, accessed on 05.11.2020.

Todorut, A. V., Cirnu, D. \& Niculescu, G. (2011), Management of business processes through reengineering, Proceedings of the 12th WSEAS international conference on Mathematics and computers in biology, business and acoustics in Transylvania University of Brasov, Romania in April 11-13, 2011, World Scientific and Engineering Academy and Society WSEAS Press, Bucharest, pp. 237-242.

What is business growth and why is it important? https://www.act.com/en-uk/business-growth, accessed on 12.11.2020.

Živković, M., Ilić, S., Bevanda, V. (2014), Ekonomika poslovanja, sedmo izmenjeno i dopununjeno izdanje, Megatrend, Beograd 